\title{
Yetişkin Ayrılma Anksiyetesi Bozukluğu: Bir Gözden Geçirme
}

\author{
Adult Separation Anxiety Disorder: A Review \\ ๑ Zeynep Naml1 ${ }^{1}$, ๑ Aynur Özbay ${ }^{1}$, ๑ Lut Tamam ${ }^{1}$ \\ 1 Çukurova Üniversitesi, Adana, Türkiye
}

Ayrılma anksiyetesi; bireyin temel bağlanma figürlerinden ayrılma ya da ayrılma beklentisi durumlarında aşırı kaygı yaşamasıdır. Ayrılma anksiyetesi bozukluğu, Ruhsal Bozuklukların Tanısal ve İstatistiksel El Kitabının beşinci (DSM-5) baskısına kadar çocukluk ve ergenlik dönemi bozukluğu olarak kabul edilmekteydi. Günümüzde ayrılma anksiyetesi bozukluğunun yetişkinlikte devam edebildiği ya da başladığ1 bilinmektedir. Yetişkin ayrılma anksiyete bozukluğu (YAAB) çocukluk dönemindekine benzer klinik belirtiler göstermektedir. YAAB'nin, anksiyete bozuklukları, travma sonrası stres bozukluğu, kişilik bozuklukları gibi çeşitli komorbid ruhsal hastalıklarla ilişkili olduğu gösterilmiştir. YAAB eşlik ettiği diğer psikiyatrik bozuklukların klinik belirtilerini ve gidişatını etkileyebilmektedir. YAAB'ye yönelik tedavi yaklaşımlarıyla ilgili yeterli veri bulunmamaktadır.

Anahtar sözcükler: ayrılma anksiyetesi, gözden geçirme, yetişkinlik

Separation anxiety is excessive anxiety in separation from or expectation of separation from basic attachment figures. Separation anxiety disorder was considered a childhood and adolescent disorder until the fifth edition of the Diagnostic and Statistical Manual of Mental Disorders (DSM-5). Nowadays, it is known that separation anxiety disorder may continue or begin in adulthood. Adult separation anxiety disorder (ASAD) shows similar clinical manifestations than in the children population. ASAD has been associated with several comorbid mental disorders such as anxiety disorders, post-traumatic stress disorder, and personality disorders. ASAD can also affect the clinical symptoms and course of comorbid psychiatric disorders. There is not enough data about the treatment approaches for ASAD.

Key words: separation anxiety, review, adulthood

\section{Giriş}

Ayrılma anksiyetesi ilk kez Ruhsal Bozuklukların Tanısal ve Sayımsal Elkitabı üçüncü versiyonunda (The Diagnostic and Statistical Manual of Mental Disorders, Third Edition)(DSMIII) bir bozukluk olarak tanımlanmıştır (APA 1987). Geçmiş yıllarda ayrılma anksiyetesi bozukluğu (AAB), çoğunlukla çocukluk çağının ruhsal hastalığı olarak kabul edilmekteydi ve erişkinliğe uzanmadığı varsayılmaktaydı. Eski tanı sınıflandırma sistemlerinde hastalığın 18 yaşından önce başlaması gerektiğine dair, yaş kriteri bulunmaktaydı (APA 1987, 2004). AAB tanısının yaşla sınırlanması nedeniyle, çocukluk AAB belirtilerinin yetişkinliğe sarkıp sarkmadığı, belirtilerin yetişkinlikte başlayıp başlamadığı soruları araştırmalara sıklıkla konu olmuştur. Costello ve ark. (2003) yaptıkları çalışmada; çocukluk çağında başlayan ayrılma anksiyetesinin çocukluk çağı ile sınırlı olduğunu ve erişkin çağa uzanmadığını bildirmiştir. Foley ve ark. (2004) 3 yıllık izlem çalışmalarında, AAB'si olan çocuklardan bazılarında belirtilerin zamanla yok olduğunu, hastalığın çocukluk ve ergenlik çağıyla sınırlı olduğunu savunmuştur. Ancak son 30 yılda yapılan araştırmalar, ayrılma anksiyetesinin ana belirtilerinin yetişkinlikte de devam edebildiğini (Manicavasaga ve ark. 1997, Silove ve ark. 2002) ve yetişkinlerde görülen AAB'nin tahmin edilenden fazla olduğunu göstermektedir (Mayseless ve Scher 2000, Cyranowski ve ark. 2002). Ayrıca AAB'nin belirtilerinin ilk kez yetişkinlikte de ortaya çıkabileceğini gösteren çalışmalar bulunmaktadır (Shear ve ark. 2006).

Yapılan çalışmalarla AAB'nin yetişkinliğe uzanabildiğinin veya yetişkinlikte başladığının görülmesi üzerine, çocukluk çağı bozukluğu olarak kabul edilmiş olan ayrılma anksiyetesi, 2013 yılında yayınlanan DSM-5 ile; bütün yaş dönemlerini kapsayan, bireylerin hayatı boyunca tanı alabileceği bir bozukluk haline gelmiştir (APA 2013). Bu derlemede, geçmişten günümüze kadar yapılan çalışmalar incelenerek yetişkin AAB'nin tanımı, etiyolojisi, epidemiyolojisi, klinik özellikleri ve prognozu ayrıntılandırılmaya çalışılmıştır.

Yazışma Adresi/Address for Correspondence: Zeynep NAMLI, Çukurova Üniversitesi Tıp Fakültesi Psikiyatri Anabilim Dalı, Adana, Türkiye 


\section{Tanım}

Anksiyete; kaynağı büyük oranda bilinmeyen, kaygı ve bunaltı halidir (Karamustafalıoğlu ve Yumrukçal 2011). Ayrılma anksiyetesi ise; temel bağlanma figüründen, ölüm, boşanma, hastalık ve diğer nedenlere bağlı olarak ayrılma sonucunda ortaya çıkan aşırı kaygı halidir. Bu kaygı sadece gerçek ayrılma durumlarında değil, ayrılma beklentisi durumunda da oluşabilmektedir. Ayrılma anksiyetesi temel olarak bağlanma teorisine dayanmaktadır (Bowlby 1973, Ainsworth 1982, Taşdemir ve ark. 2016).

Ayrılma anksiyetesi; özellikle 1 yaş öncesi bebeklerde, anneden veya bakım verenden ayrıldıktan sonra, özvarlığını tehlikede hissetme nedeniyle gözlenmektedir. Bu anksiyete, bakım veren kişi tarafından giderilmektedir. Çoğunlukla sekizinci ayda başlar, 12-15. aylarda en yüksek seviyeye ulaşır ve 3-5 yaşlarda yatışmaktadır (Bowlby 1973, Bowlby 1980). Ayrılma anksiyetesi çocuklarda normalden sapma olarak kabul edilmemekle birlikte bilişsel gelişimin sağliklı olduğuna işaret etmektedir. Bu durum kendini korumada yetersiz olan çocuğun annesini ya da bakım veren kişiyi çevresinde tutmasına yarayan gelişimsel uyumsal bir mekanizmadır (Bowlby 1973). Bazen okula başlayan çocuklarda kısa süreli ve bir miktar ayrılma anksiyetesi görülebilmektedir. Ayrılma anksiyetesinin uzun sürmesi, şiddetli ve gelişimsel açıdan uygunsuz olması ya da işlevselliği bozması durumunda AAB tanısı konulmaktadır (Bögels ve ark. 2013).

Yetişkinlikteki ayrılma anksiyetesi belirtilerinin, ebeveynlerden olduğu kadar "eşten veya çocuklardan ayrılmaya" ya da "başlarına bir zarar geleceğine” ilişkin aşırı kaygı duymaya dönüşebildiği belirtilmektedir. Evden ayrılma, çocuk sahibi olma, duygusal bir ilişki yaşamanın ayrılma anksiyetesini başlatabileceği ileri sürülmüştür (Bögels ve ark. 2013). Yetişkin ayrılma anksiyetesi bozukluğu (YAAB) tanılı kişiler, önemli bağlanma nesnelerinden (eş, çocuk, anne, baba vs.) ayrılma durumlarında aşırı kaygılanmakta, bağlanma nesnelerine devamlı yakın olma ihtiyacı hissetmekte ve bir süre sonra bağlanma nesnelerinden ayrilamaz hale gelmektedirler (Mayseless ve Scher 2000). AAB tanılı yetişkinler sıklıkla, yaşamlarının erken yıllarından itibaren ayrılma anksiyetesi belirtilerinin olduğunu ifade etmektedir ve bu veri, AAB'nin çocuk ve yetişkin biçimleri arasında bir süreklilik olduğunu düşündürmektedir (Manicavasaga ve ark. 1997).

\section{Epidemiyoloji}

Yetişkinlerin değerlendirildiği geniş örneklemli ulusal komorbidite araştırmasında (National Comorbidity Survey Replication-NCS-R) YAAB'nin yaşam boyu yaygınlığı 6,6\%, bir yıllık prevelansı \%1,9 olarak belirlenmiştir (Shear ve ark. 2006). YAAB belirtilerinin çoğunlukla erişkin dönemde başladığı, sadece üçte birinin çocukluk çağında başlayıp erişkin döneme uzandığ1 tespit edilmiştir (Shear ve ark. 2006). Dünya Sağlık Örgütü'nün (DSÖ) Dünya Ruh Sağlığı Araştırmalarından elde edilen verileri değerlendirilerek yapılan çalışmada, 18 ülkede, yaklaşık 39 bin kişilik toplum temelli popülasyonda $\mathrm{AAB}$ yaygınlığının \% 4,8 gibi yüksek bir orana sahip olduğu ve örneklemin \% 43,1'inin hastalığının 18 yaşından sonra başladığı belirlenmiştir (Silove ve ark. 2015).

Manicavasagar ve arkadaşları (2000) panik bozukluk ve yaygın anksiyete bozukluğu tanılı yetişkin hastalarda AAB'yi araştırmıştır ve örneklem grubunun neredeyse yarısında YAAB eş tanısı belirlenmiştir. Ülkemizde yakın tarihli bir araştırmada, yaygın anksiyete bozukluğu tanılı hastalar değerlendirilmiş ve hastaların \% 45'inde YAAB eş tanısı belirlenmiştir (Demir ve Görgülü 2020).

YAAB yaygınlığını inceleyen, farklı yaş gruplarının dahil edildiği çalışmalar bulunmaktadır. Üniversite öğrencilerinin değerlendirildiği bir çalışmada YAAB sıklığı \%21, altmış yaş üstü katılımcıların dahil olduğu geriatrik bir grupta \%6, hastanede doğum öncesi kliniğe başvuran gebe kadınlarda \%24,5 olarak saptanmıştır (Wijeratne ve Manicavasagar 2003, Seligman ve Wuyek 2007, Eapen ve ark. 2012)

Araştırmalarda YAAB tanısının çocukluk ya da yetişkin başlangıçlı olup olmadığı da değerlendirilmiştir. Ulusal komorbidite araştırmasında, yaşam boyunca herhangi bir dönemde YAAB tanısı konulan hastaların \%77,5'nin ve 12 aylık periyodda YAAB tanısı alan hastaların \%75,2'sinin erişkin başlangıçlı AAB tanısı olduğu saptanmıştır (Shear ve ark. 2006). Yapılan klinik bir çalışmada erişkin başlangıçlı ayrılma anksiyetesi ile çocukluk çağından erişkinliğe kadar devam eden ayrılma anksiyetesinin benzer oranlarda olduğu tespit edilmiştir (Pini ve ark. 2010). Ancak erişkin başlangıçlı ayrılma anksiyetesinin tüm ayrılma anksiyetesine oranının 1/4, 1/3 olarak saptandığı çalışma sonuçları da bulunmaktadır (Manicavasaga ve ark. 1997, Silove ve ark. 2010). Okula başlama sonrası oluşan anksiyete ile ilgili yapılan bir çalışmada; 72 kişinin 16'sının YAAB tanısı olduğu ve YAAB tanısı alanların \%25'nin erişkin başlangıçlı olduğu tespit edilmiştir (Silove ve ark. 2002).

Çocukluk çağında AAB (ÇAAB) genellikle 7-8 yaşlarında saptanmaktadır (Alfano ve ark. 2002, Bögels ve ark. 2003). ÇAAB'nin erken çocukluk döneminde başladığı, çocukluk çağından başlayıp erişkinliğe uzanan ayrılma anksiyetesinin 10'lu yaşlarda başladığı, erişkin başlangıçlı ayrılma anksiyetesinin ise 20'li yaşlarda başladığı vurgulanmaktadır (Shear ve ark. 2006). Altıış yaş üstü bireylerde ayrılma anksiyetesi çok nadir görülmektedir ve ileri yaşlarda huzur evine yerleşme, sevdiklerinin ölümü gibi nedenler ayrılma anksiyetesinin oluşumuna neden olabilmektedir (Wijeratne ve Manicavasagar 2003).

Psikiyatri polikliniğine başvuran anksiyete bozuklukları ve/veya depresif bozukluk tanılı örneklemin incelendiği bir çalışmada; erkeklerin \%24'ünde, kadınların \%30'unda YAAB tanısı saptanmıştır (Cyranowski ve ark. 2002). Toplum taramalarında YAAB tanısının kadınlarda 1,4 kat fazla olduğu belirlenmiştir. Ancak ÇAAB tanısının özellikle kadınlarda fazla olduğu, YAAB'de cinsiyet farklılığının azaldığı belirtilmiştir (Shear ve ark. 2006). Erişkin başlangıçlı YAAB'ın ise; erkeklerde daha fazla olduğu çalışma sonuçları arasında yer almaktadır (Shear ve ark. 2006, Silove ve ark. 2010). Çalışma sonuçları özetlenecek olursa; AAB hem yetişkinlik hem de çocukluk döneminde kadınlarda daha 
fazla görülmektedir ve YAAB'nin erkeklerde görülme oranı çocukluk dönemine göre daha yüksektir. Bu yükseklik ayrilma anksiyetesinin çocukluktan yetişkinliğe devam etme oranının erkeklerde kadınlardan daha yüksek olması ya da yetişkinlik döneminde erkeklerde kadınlara göre başlama olasılığının daha fazla olması ile açıklanabilir.

Toplum örneklemlerindeki YAAB tanılı hastaların sağlık kontrollere göre daha düşük eğitim düzeyine sahip olduğu, bekar-boşanmış ve işsizlik oranlarının daha yüksek olduğu bulunmuștur. Yaş ve eğitim süresi arttıkça YAAB oranının azaldığı bildirilmektedir (Shear ve ark. 2006). Ancak bu verilerin aksine, yapılan klinik bir çalışmada YAAB'nin evlilik durumu, işsizlik ve eğitim düzeyi ile ilişkili olmadığı belirlenmiştir (Pini ve ark. 2010).

Sosyodemografik verilere ek olarak, ayrilma anksiyetesinin kültürel yapilardan etkilenmesi beklenmektedir. Anne ayrilma anksiyetesi üzerine yapılan çalışmaların çoğu batı toplumlarında, yani bireyci kültürlerde yürütülmektedir. Ayrılma anksiyetesi benliğin daha az farklılaşmasıyla ilişkili olduğundan ve toplulukçu kültürlerde birbirine bağlılık, bağımsızlığa daha fazla odaklanan bireyci kültürlerden daha önemli olduğundan, toplulukçu kültürlerde ayrılma anksiyetesi belirti düzeylerinin daha yüksek olabileceği tahmin edilmektedir. Ancak kaygının kültürel normlara göre aşırı olması gerektiği göz önüne alındığında, bireyci kültürlerde de $\mathrm{AAB}$ daha yüksek olabilmektedir (Heinrichs ve ark. 2006). Ayrıca, savaş, yoksulluk veya tehlikeli bir ortamda yaşamak gibi sevilen birini kaybetme ihtimalini artıran gerçek tehditler ayrilma anksiyetesini etkileyebilir ve bu nedenle bu tür koşullara daha fazla maruz kalan kültürlerde $\mathrm{AAB}$ daha yaygın olabilmektedir (Peleg ve ark. 2006).

\section{Etiyoloji}

Ayrılma anksiyetesinin oluşumu bağlanma kuramından köken almaktadır. Kurama göre; bağlanma figüründen ayrıldıktan sonra oluşan stresle başa çıkma biçimi, çocuğun duygularını düzenlemesinde ve güven duygusunu hissetmesinde ana rol oynamaktadır. Bakım veren kişi ya da kişilerle kurulan ilk ilişkinin daha sonra kurulacak yakın ilişkilere öncülük ettiği bilinmektedir. Bu nedenle bakım veren-bebek arasında oluşan bağlanma biçimi önemlidir. (Weinfield ve ark. 1997, Ditommaso ve ark. 2003). Olumsuz ebeveynlik biçimleri (eleştirel, aşırı koruyucu, ihmalkar vb) erken dönemde çocuğun gereksinimlerinin sağlık ı bir biçimde karşılanmamasına neden olabilmektedir. Sorunlu ya da zayıf bağlanma biçimleri; çocukluk çağında olduğu gibi yetişkinlik döneminde de birçok psikolojik problem için risk faktörü olarak görülmektedir (Weinfield ve ark. 1997, Başbuğ ve ark. 2016).

ÇAAB oluşumunda annede olan ayrilma anksiyetesinin etkili olabileceği düşünülmektedir. Annede oluşan ayrilma anksiyetesinde; annenin daha az olgunlaşmış bir kişiliğe sahip olması, düşük benlik saygısı, olumsuz kendilik algısı, reddedilme karşısında yetersiz baş etme yolları, güvensiz bağlanma figürleri ve kendi ailesinden ayrildıktan sonra gösterdiği cesaret önemli bulunmuştur. Annede, ayrllıktan sonra oluşan yüksek anksiyetenin güvensiz bir şekilde bebeğine bağlanmasına, bebek bakımı konusunda güvensiz davranışlar geliştirmesine ve aşırı koruyucu olmasına neden olduğu belirtilmiştir. $\mathrm{Bu}$ sonuçların da çocukta ayrılma anksiyetesi gelişimine etki ettiği düşünülmektedir (Hock ve ark. 1989).

YAAB tanılı kişilerin annelerinin genellikle aşırı koruyucu olduğu bildirilmiştir ve aşırı koruyuculuk anksiyöz bağlanma biçimine neden olabilmektedir (Manicavasagar ve ark. 1999). Manicavasagar ve ark. (2009) panik bozukluk tanılı hastalara kıyasla YAAB ile "anksiyeteli bağlanma biçimi" arasında, daha güçlü korelasyon olduğunu ve YAAB tanılı hastaların onaylanma ihtiyaçlarının daha fazla olduğunu saptamıştır.

Ayrılma anksiyetesi etiyolojisine yönelik yapılan çalışmalar net sonuçlar ortaya koymasa da nevrotizm ile ilişkisi olduğuna dair kanitlar mevcuttur. Ayrilma anksiyetesi olan nevrotizmli bireylerde anksiyete ve duygudurum değişikliklerinin kalıtsal bir alt yapisı olduğu öne sürülmüştür (Lahey 2009) ve özellikle bu genetik alt yapının kadınlarda daha belirgin olduğu iddia edilmiştir (Eaves ve ark. 1997). Geçmiş bir çalışmada YAAB tanısı olan olguların nevrotizm ile ilgili skorlarında anlamlı yükselmeler gösterilmiştir (Silove ve ark. 2010). Bazı çalışmacılar da nevrotizm ile ayrılma anksiyetesi arasındaki ilişkinin özgül olmadığını ve kişiler arası ilişkinin bir parçası olduğunu savunmuştur (Wilhelm ve ark. 2004).

\section{Genetik ve Nörobiyoloji}

Yetişkinlerde ayrılma anksiyetesi ile ilgili genetik çalışmalar sinırlıdır, araştırmalar genellikle ÇAAB üzerine yoğunlaşmıştır (Roberson-Nay ve ark. 2012). Çocukluk döneminde ayrilma anksiyetesi olan kişilerin kardeşlerinde veya çocuklarında okul reddinin daha sık olduğu gösterilmiştir (Silove ve ark. 1993). $\mathrm{AAB}$ olan çocukların 1 ve 2 . derece akrabalarında yüksek oranda AAB saptanmaktadır. Yapılan aile çalışmalarında AAB'nin aile içi geçişinin olduğuna dair kanıtlar mevcuttur. Annede görülen ayrılma anksiyetesinin çocukta görülen ayrılma anksiyetesi ile anlamlı olarak ilişkili olduğu gösterilmiştir (Peleg ve ark. 2006). Sadece YAAB tanısı değil, ebeveynlerdeki diğer anksiyete bozukluklarının da ÇAAB için risk oluşturduğu bildirilmiştir (Nestadt ve ark. 2001, Strober ve ark. 2007).

$\mathrm{AAB}$ açısından aile-çocuk uyumunu incelemek amacıyla, ÇAAB tanısı alan çocuk ve ailelerinin değerlendirildiği bir çalışmada; çocukların \%63'ünün aile üyelerinden en az biri YAAB tanısı almıştır. Bu aileler kendi çocukluk dönemleri için de yüksek düzeyde ayrılma anksiyetesi bildirmiştir (Manicavasagar ve ark. 2001).

İkiz çalışmasında; anne ve kız çocuğu için ailevi kümelenme özelliklerinin daha güçlü olduğu ve kadın cinsiyetin ayrılma anksiyetesi için daha güçlü bir genetik yük olabileceği belirtilmiştir (Silove ve ark. 1995). Monozigot ve dizigot çocuklarda yapılan çalışmalarda; yaşam boyu ayrılma anksiyetesi yaygınlığının yüksek olduğu saptanmıştır ve monozigotlardaki oran daha yüksek bulunmuştur (Bolton ve ark. 2006, Ehringer ve ark. 2006, Ogliari ve ark. 2010). Sonuçlara rağmen AAB gelişiminde çevresel etkinin önemli olduğu vurgulanmıştır (Eley ve ark. 2008). Tüm bu kalıtımsal etkinin sadece ayrılma anksiyetesinde olmadığı, diğer 
anksiyete bozukluklarında da olabileceği ve kalıtımın hastalığa küçük bir katkısı olduğu belirtilmiştir (Gregory ve Eley 2007).

Ayrılma anksiyetesi için tanımlanmış bir biyolojik belirteç yoktur. Anksiyete bozukluklarında akut veya kronik streste trombositlerdeki $18 \mathrm{kDA}$ translokatör protein (TSPO) (eski adıyla periferal tip benzodiazepin reseptör bağlanma yerleri) yoğunluğunun değiştiği gösterilmiştir ( $\mathrm{Da}$ Pozzo ve ark. 2012). Yapılan araştırmalarda; bipolar bozukluk (Abelli ve ark. 2010) ve panik bozukluk (Pini ve ark. 2005) tanılı hastalardan sadece YAAB eşlik edenlerin TSPO düzeylerinin belirgin düşük olduğu, depresif bozukluk tanılı hastalarda da (Chelli ve ark. 2008) YAAB semptomlarıyla ilişkili TSPO yoğunluğunda azalma saptanmıştır. Ayrıca translokatör proteinde 147. bölgedeki Ala ile Thr yer değişikliğinin, depresyon tanılı hastalarda yetişkin ayrılma anksiyetesi ile ilişkili olduğu belirlenmiştir (Costa ve ark. 2009a). Çalı̧̧malarda, TSPO düzeyinin özellikle eşlik eden psikopatolojilerden dolayı özgül olmayan bir biyolojik belirteç olduğu belirtilmiştir (Pini ve ark. 2005, Chelli ve ark. 2008).

Oksitosinin bağlanma süreçlerini etkileyen bir nörotransmiter/ nöromodülatör olduğu ve sosyal bağların gelişmesinde rol oynadığı bilinmektedir (Tops ve ark. 2007). Hipotalamopituitier-adrenal sistem oksitosinerjik sistemle bağlantılıdır. Yetişkinlerde bağlanma kaygısının akut strese kortizol yanıtı ile ilişkili olduğu ve (Quirin ve ark. 2008) olumlu bağlanmanın oksitosin ve kortizol seviyelerini düzenleyerek stresi azalttığ1 saptanmıştır (Tops ve ark. 2007). Erken ebeveyn kaybı yaşamış olan yetişkinlere oksitosin uygulanan bir çalışmada; oksitosine kortizol azalması yanıtının zayıfladığı belirlenmiştir (Meinlschmidt ve Heim 2007). Bu nedenle oksitosin ile ayrılma anksiyetesinin ilişkili olabileceği düşünülmektedir (Costa ve ark. 2009b). YAAB tanılı hastalarda bu konuda yapılan çalışmalar kısıtlıdır. Genetik bir çalışmada oksitosin prohormon bölgesi ve promoter bölgesindeki mutasyonlar, polimorfizmler incelenmiştir (Costa ve ark. 2009b). Depresif bozukluk, depresif bozukluğa eşlik eden YAAB ve kontrol grubu olmak üzere üç grubun incelendiği çalışmada, polimorfizm oranlarının birbirine yakın olduğu bulunmuştur. Çalışma verileriyle oksitosinin sadece ayrilma anksiyetesinde değil birçok ruhsal hastalıkta rol oynadığı bildirilmiştir (Costa ve ark. 2009b).

Bağlanmada moleküler genetik çalışmalar, oksitosin dışında dopamin ve serotonin reseptör genleri üzerine de odaklanmıştır. Annenin yaşadığı kayıp ya da travmaların, çocukta bağlanma problemleri oluşturmasında dopamin genindeki DRD47-yineleme polimorfizminin rol oynadığı gösterilmiştir. Bu genin ÇAAB'de rol alabileceğine dair destekleyici çalışmalar bulunmaktadır (Van Ijzendoorn ve Bakermans-Kranenburg 2006, Gadow ve ark. 2010). Diğer bir araştırmada DRD2 dopamin reseptör genindeki polimorfizmin anksiyöz bağlanmayla ve 5HT2a serotonin reseptör genindeki polimorfizmin ise kaçıngan bağlanmayla ilişkili olduğu saptanmıştır (Gillath ve ark. 2008).

Panik bozukluk ile karbondioksit $\left(\mathrm{CO}_{2}\right)$ aşırı duyarlılı̆ı̆ını ilişkisi bilinmektedir. YAAB tanılı hastalarda yapılan bir çalışmada, hastaların panik bozukluk tanılı hastalara benzer oranlarda CO2 aşırı duyarllığı olduğu bulunmuştur (Atlı 2011). Çalışma sonuçları $\mathrm{CO} 2$ aşırı duyarlılığının panik bozukluk ve AAB'de ortak bir biyolojik belirteç olabileceğini düşündürmüştür (Pine ve ark. 2005). Sadece ayrilma anksiyetesi olmamak kaydiyla tüm anksiyete bozukluklarında özellikle de yaygın anksiyete bozukluğu (YAB), sosyal fobi (SF) ile Williams Sendromunun ilişkili olduğuna dair bulgular gösterilmiştir (Leyfer ve ark. 2009).

\section{Nörogörüntüleme}

Nörogörüntüleme çalışmaları sinırlıdır ve yapılan çalışmalarda bağlanma kaygısı sol hipokampal volümde azalmayla ilişkilendirilmiştir (Quirin ve ark. 2010). AAB ile ilişskilendirilen anksiyözbağlanmaya sahip erişkinlereöfkeliyüzlergösterildiğinde sol amigdala aktivitesinde artış olduğu saptanmıştır (Vrtička ve ark. 2008). Oksitosin uygulanması ile korku verici görsel imgelere olan amigdala yanıtlarının düzenlendiği gösterilmiştir (Kirsch ve ark. 2005)

$A A B$ ile bellek defisiti ilişkisine dair çalışma sonuçları bulunmaktadır. Görsel ve işitsel bellek fonksiyonları ile ilgili çocuklar ve aileleri üzerinde yapılan bir çalışmada işitsel bellek defisitinin ÇAAB ile ilişkisi olmadığı bulunmakla beraber görsel bellek defisitinin ÇAAB ile ilişkili olabileceğine dair vurgu yapılmıștır (Vasa ve ark. 2007). Diğer bir çalışmada ise; işitsel ve görsel bellek defisitinin $\mathrm{AAB}$ dahil tüm anksiyete bozuklukları için prediktör olduğu ileri sürülmüştür (Pine ve ark. 1999).

\section{Çevresel Risk Faktörleri}

Erken yaşam olayları ve çocukluk çağı travmalarının psikopatoloji gelişiminde etkin rol oynadığ bilinmektedir. AAB belirtileri, ebeveyn kaybı gibi özellikle olumsuz bir yaşam olayından sonra başlayabilmektedir (Alkın 2010).

ÇAAB ile ilgili davranış-genetik çalışmaları, özellikle erkek çocuklarda çevresel risk faktörlerinin önemli olduğunu göstermektedir ancak bu çalışmalar YAAB için yapılmamıştır. Komorbidite üzerine yapılan çalışmalar YAAB'nin olası çevresel risk faktörleri hakkında bilgi sağlamaktadır. YAAB ve travma sonrası stres bozukluğunun sık birliktelik göstermesi, travmaya dair korkuların YAAB için risk faktörü olduğunu, YAAB ile uzamış yas arasındaki güçlü ilişki de sevilen kişinin kaybının diğer bir risk faktörü olduğunu düşündürmektedir (Bögels ve ark. 2013).

Ebeveynliğin, YAAB için diğer bir çevresel risk faktörü olabileceği düşünülmektedir. Çocuklarda ebeveyn müdahaleciliği ile AAB'nin ilişkili olduğu gösterilmiştir (Wood 2007). Yetişkinlerde de geriye dönük olarak annenin aşırı korumacıllğına dair bildirimler ile YAAB'nin ilişkili olduğu bulunmuştur (Manicavasagar ve ark. 1999, Bögels ve ark. 2013).

YAAB için çevresel risk faktörleri, belirli gelişim dönemleriyle bağlantılı olabilmektedir. Dolayısıyla çocukların bağımsız hale gelmeleri, bağlanma ilişkisinin kalitesine bağlı olarak YAAB için çevresel bir risk faktörü haline gelebilmektedir (Bögels ve ark. 2013). 


\section{Klinik Özellikler ve Tanı}

Yetişkinlikteki ayrilma anksiyetesi belirtileri, ebeveynlerden ayrılma korkusu kadar, eşten ya da çocuklardan ayrılmaya veya yakınlarının başına bir zarar geleceğine dair aşırı kaygı ve korku duymaya dönüşmektedir (Manicavasaga ve ark. 1997). YAAB olan hastalar bağlanma figürleriyle yakınlığı ya da yakın iletişimi sürdürme gereksinimleri nedeniyle yoğun bir endişe hali içindedirler (Silove ve ark. 2007) ve bu bireyler kaygılarını 'aşırı, egodistonik ve kısıtlayıcı' şeklinde tanımlamaktadır (Manicavasagar ve ark. 2010). Kaygılarını denetlemekte ve davranışlarına yansıtmamakta güçlük çekmektedirler. Çocuklarda evden ayrılmamak için okula gitmeyi reddetme gibi yetişkinler de işe gitmek istemeyebilirler (Manicavasagar ve ark. 2009). İşe geç gitme, gitmeme, evde zaman geçirme, başka bir kentte okumayı reddetme gibi baş etme ya da kaçınma davranışlarıyla yakınlığı sürdürmek için çabalamaktadırlar (Alkın 2010). Ayrilık içerikli kâbuslar sıktır ve yalnız uyumaktan kaçınmaktadırlar. Ayrılma halinde veya beklentisinde panik atak geçirebilirler (Manicavasaga ve ark. 1997). Yapılan bir araştırmada hastaların yarısından fazlası evde yakınlarıyla birlikteyken kendilerini daha güvende hissettiklerini ifade etmiştir (Seligman ve Wuyek 2007).

Çocukluk ve yetişkinlik döneminde görülen ayrılma anksiyetesi belirtileri bazı farkllıklar haricinde birbirine benzerlik göstermektedir (Silove ve ark. 2010). Çocukluk ayrilma anksiyetesinde mide bulantısı, karın ağrısı gibi bedensel belirtiler ağırlık gösterirken, erişkin dönemde bilişsel ve duygusal belirtiler ön plandadır (Silove ve ark. 2007).

AAB DSM-IV-TR'de genellikle ilk kez bebeklik, çocukluk ya da ergenlik döneminde tanısı konan bozukluklar başlığı altında, bebeklik, çocukluk ya da ergenliğin diğer bozukluklarından biri olarak sınıflandırılmıştır (APA 1994). DSM-5'te ise; anksiyete bozuklukları başlığı altında yer almaktadır (APA 2013).

\section{Ayrılma Anksiyetesi Bozukluğu DSM-5 Tanı Ölçütleri}

A. Aşağıdakilerden üçünün (ya da daha fazlasının) olması ile belirli, kişinin bağlandığı insanlardan ayrılmasıyla ilgili, gelişimsel olarak uygunsuz ve aşırı düzeyde kaygı ya da korku duyması:

1. Evden ya da bağlandığı başlıca kişilerden ayrılacak gibi olduğunda ya da ayrıldığında yineleyici biçimde aşırı sıkıntı duyma

2. Bağlandığı başlıca kişileri yitireceğine ya da onların başına hastalık, yaralanma, ölüm gibi kötü bir olay geleceğine ilişkin sürekli ve aşırı bir kaygı duyma

3. Bağlandığı başlıca kişilerden ayrılmasına yol açacak, kaybolma, kaçırılma, kaza geçirme gibi istenmedik bir olay yaşayacağına ilişkin sürekli ve aşırı bir kaygı duyma

4. Ayrrlma korkusundan ötürü, sürekli olarak, okula, işe ya da başka bir yere gitmek için dışarı çıkmayı, evden uzaklaşmayı istememe ya da buna karşı koyma

5. Evde ya da başka ortamlarda tek başına kalmaktan ya da bağlandığı başlıca kişilerle birlikte olamamaktan, sürekli ve aşırı bir korku duyma ya da bu konuda isteksizlik gösterme
6. Bağlandığı başlıca kişilerden biri yanında olmadan ya da evinin dışında uyuma konusunda sürekli bir isteksizlik gösterme ya da buna karşı direnme

7. Ayrilma konusunda sürekli kâbuslar görme

8. Bağlandığı başlıca kişilerden ayrıldığında ya da böyle bir ayrılık söz konusu olduğunda tekrarlayan fiziksel belirtiler gösterme (baş ağrısı, karın ağrısı, bulantı ya da kusma gibi)

B. Bu korku, kaygı ya da kaçınma süreklilik gösterir, çocuklar ve ergenlerde en az dört hafta, yetişkinlerde ise en az altı ay devam eder.

C. Bu bozukluk, klinik açıdan belirgin bir sıkıntıya ya da toplumsal, okulla ilgili, işle ilgili alanlarda ya da önemli diğer işlevsellik alanlarında işlevsellikte düşmeye yol açar.

D. Bu bozukluk, otizmde görülebilen değişikliğe aşırı direnç gösterme nedeniyle evden uzaklaşmaya karşı koyma, psikoz ilişkili bozukluklarda ayrılık ile ilgili varsanılar ya da sanrılar, agorafobide güven duyulan biri olmadan evden çıkmaya direnme, yaygın anksiyete bozukluğu kapsamında değer verilen diğer bireylere kötü bir olay (hastalık gibi) gelmesinden endişelenme ya da hastalık anksiyetesi bozukluğunda sürekli hasta olma ile ilgili endişe duyma gibi diğer ruhsal bozukluklar ile daha iyi açıklanamaz (APA 2013).

DSM-IV-TR'de yer alan 'başlangıcı 18 yaşından önce olur' tanı kriterinin DSM-5'te yer almaması yetişkin başlangıçlı AAB tanısının konulmasına imkan sağlamıştır.

\section{Ayrılma Anksiyetesini Değerlendiren Psikometrik Ölçekler}

Ayrılma anksiyetesini değerlendirmek amacıyla Silove ve arkadaşları (1993) Ayrılma Anksiyetesi Belirti Envanteri'ni (AABE) (Separation Anxiety Symptom Inventory) geliştirmiştir. Çocuklukta yaşanmış olması muhtemel olan ayrılma anksiyetesi belirtilerini, geriye dönük sorgulayan 15 maddeli bir envanterdir. Manicavasagar ve ark. (2003) yetişkinlik dönemindeki ayrılma anksiyetesi belirtilerini sorgulayan 27 maddelik Yetişkin Ayrılma Anksiyetesi Anketi'ni (YAAA) (Adult Separation Anxiety Checklist) geliştirmiştir. Her iki ölçeğin Türkçe geçerlik ve güvenirliği gösterilmiştir (Diriöz ve ark. 2012a).

Cyranowski ve arkadaşları (2002) Ayrılma Anksiyetesi Belirtileri için Yapılandırılmış Klinik Görüşme (AAB-YKG) (Structured Clinical Interview for Separation Anxiety Symptoms) olarak adlandırılan klinik görüşmeyi geliştirmiştir. Yetişkinlerde kullanılmak üzere geliştirilen bu yapılandırılmış görüşme 8'er maddelik 2 kısımdan oluşmaktadır. İlki geriye dönük olarak çocukluk $A A B$, diğeri ise yetişkinlik $A A B$ tanı ölçütlerini değerlendirmektedir. Türkçe geçerlik ve güvenirliği gösterilmiştir (Diriöz ve ark. 2012b). DSM-5 Ayrilma Anksiyetesi Bozukluğu Şiddet Ölçeği- erişkin formu (DSM-5 Separation Anxiety Disorder Severity Scale- adult form) yetişkinlikte ayrılma anksiyetesi belirtilerinin şiddetini 
belirlemek için kullanılan, 10 maddeden oluşan bir öz bildirim ölçeğidir. DSM-5 tanı kriterlerine uygun olarak hazırlanmış olması nedeniyle $A A B$ semptomlarını sorgulamada ve $A A B$ şiddetini ölçmede yardımcı olmaktadır. Türkçe versiyonun geçerli ve güvenilir olduğu gösterilmiştir (Coldur ve ark. 2020).

Ebeveyn Ayrılma Anksiyetesi Ölçeği (Parental Separation Anxiety Scale), Anne Ayrılma Anksiyetesi Ölçeği (Maternal Separation Anxiety Scale) anne ve babaların çocuklarından ayrıldıklarında yaşadıkları ayrılma anksiyetesini değerlendiren ölçeklerdir (Hock ve ark. 1989, Dashiff ve Weaver 2008).

YAAB işlevsellik kaybına sebep olmaktadır ve ek tanı varlığında yetiyitimi şiddetlenmektedir (Shear ve ark. 2006, Kessler ve Wang 2008). Özellikle mesleki ve toplumsal işlevlerde kayıp olurken, partner ile ilişkiler etkilense de aile ilişkilerindeki işlevselliğin görece korunduğu belirlenmiştir (Manicavasaga ve ark. 1997, Pini ve ark. 2010). Epidemiyolojik bir araştırmada, YAAB olan olguların \%21,1'i ev işlerinde, \%21,7'si iş hayatında, \%28'i kişisel ilişkilerinde ve \%31,5’i sosyal ilişkilerinde belirgin bozulma olduğunu bildirmiştir (Shear ve ark. 2006). Anksiyete ve depresif bozukluğu olan hastalarda yapılan bir çalışmada YAAB tanısının performansta ve kişilerarası ilişkilerde belirgin etkilenmeye neden olduğu belirtilmiştir. ÇAAB, çocuklukta başlayıp yetişkinliğe devam eden YAAB ve yetişkin başlangıçlı YAAB'nin işlevsellik düzeyine etkisinin benzer olduğu saptanmıştır (Pini ve ark. 2010).

\section{Eştanılar}

Anksiyete bozuklukları, duygudurum bozuklukları ve travma sonrası stres bozukluğu ayrılma anksiyetesine en sık eşlik eden ruhsal hastalıklardır (Shear ve ark. 2006). Literatürde anksiyete bozuklukları baskın olmak üzere ruhsal hastalıklara eşlik eden AAB tanısına yönelik çalışma sonuçları bulunmaktadır.

YAAB'de başta anksiyete bozuklukları olmak üzere eş tanı oranlarının yüksek olduğu görülmüştür (Silove ve ark. 2010). Epidemiyolojik çalışmalarda, YAAB tanılı hastalarda \%91,1 oranında en az bir psikiyatrik hastalık tanısı daha olduğu ve yaşam boyu eş tanı sıklık oranları; herhangi bir anksiyete bozukluğu için \%67, duygudurum bozukluğu için \%62 olarak bildirilmiştir. AAB tanısı olanlarda, olmayanlara göre; 3 kat fazla ilaç kötüye kullanımı, 5 kat fazla anksiyete bozukluğu, 4 kat fazla duygudurum bozukluğu olduğu belirlenmiştir (Cartwright ve ark. 2006, Shear ve ark. 2006). Manicavasaga ve arkadaşları (1997) yapmış olduğu çalışmada; YAAB tanısı olan hastalarda \%67 oranında ruhsal hastalık ek tanısı saptamış ve yaşam boyu hastaların \%69'unda major depresif bozukluk öyküsü olduğunu bildirmiştir.

Obsesif kompulsif bozukluk (OKB) tanılı hastalara eşlik eden ruhsal hastalıkların değerlendirildiği bir vaka kontrol çalışmasında; AAB tanısı belirlenen hastalarda \%10,7 oranında hipokondriyazis, \%7,4 panik bozukluk+agorafobi, \%6,3 OKB, $\% 4,2$ patolojik cilt yolma ve tırnak yeme, \%3,7 yaygın anksiyete bozukluğu ve \%2,6 oranında major depresif bozukluk eş tanıları saptanmıştır (Nestadt ve ark. 2001). Yakın dönemde yapılan bir çalışmada ise; OKB tanılı yetişkinlere AAB eşlik etme oranı \%4,4 olarak belirlenmiştir (Franz ve ark. 2015).

Silove ve arkadaşlarının (2010) anksiyete bozuklukları tanılı hastaların dahil edildiği çalışmasında; YAAB tanı kriterlerine yönelik değerlendirme yapılmadan önce, örneklemde \%23 oranında panik bozukluk, \%31 panik bozukluk+agorafobi, \%26 yaygın anksiyete bozukluğu ve \%20 oranında sosyal fobi belirlenmiştir. YAAB tanı kriterleri göz önünde bulundurularak hastalık dağılımları tekrar değerlendirildiğinde; \%23 YAAB, \%12 panik bozukluk, \%11 panik bozukluk+agorafobi, \%21 yaygın anksiyete bozukluğu ve \%14 oranında sosyal fobi bulunmuştur. En belirgin küçülme panik bozukluk + agorafobi grubunda olmuştur ve ayrıca grubun \%49'unda YAAB tanısı belirlenmiştir. Bu çalışma ile YAAB'ye en sık eşlik eden hastalığın panik bozukluk ve agorafobi olabileceği sonucuna varılmıştır (Silove ve ark. 2010). YAAB’ye panik bozukluğun sıklıkla eşlik ettiğini destekler nitelikte, Manicavasagar ve arkadaşları (2000, 2009) iki farklı epidemiyolojik araştırmada panik bozukluğa YAAB'nin eşlik etme oranlarını \%65 ve \%46 olarak bildirmiştir.Ülkemizde ayrılma anksiyetesinin değerlendirildiği çalışmalarda; bipolar bozukluk tanılı hastalarda \%54 (Tasdemir ve ark. 2016), major depresif bozukluk tanılı hastalarda \%41 (Elbay ve ark. 2021) oranında YAAB tanısı belirlenmiştir.

Çocukluk başlangıçlı olmayan YAAB'nin, yetişkinlikte sevilen kişilerin travmatik kaybından sonra başlayabildiği ve böylece komplike yasın ve travma sonrası stres bozukluğu (TSSB)'nun eşlik ettiği bildirilmiştir (Bögels ve ark. 2013). Çocukluk dönemi AAB belirtileri yetişkin dönemde devam eden hastaların komplike yas açısından yüksek risk altında olduğu, YAAB'nin erişkinlerde görülen komplike yas ile ÇAAB arasında aracı rol oynadığı belirlenmiştir. Bu sonuç sevilen birinin kaybının erken dönem ayrılma kaygılarını tetikleyebileceğini düşündürmektedir (Wijeratne ve Manicavasagar 2003, Vanderwerken ve ark. 2006). Komplike yas ile YAAB ilişkilendirilmektedir çünkü travmatik kayıplar aynı zamanda YAAB için de tetikleyici olabilmektedir (Wijeratne ve Manicavasagar 2003). YAAB tanılı hastalarda yapılan bir çalışmada, katılımcıların \% 33'ü belirtilerinin başlangıcında büyük bir kayıp yaşadığını bildirmiştir (Manicavasaga ve ark. 1997). Mülteciler ile yapılan bir çalışmada ise; YAAB tanısı olan hemen her kişide eşlik eden TSSB tanısı olduğu ancak TSSB olanların yarısında ek YAAB tanısı olduğu belirlenmiştir (Silove ve ark. 2010). YAAB'nin çoğu çalışmada özellikle panik bozukluk ve agorafobiye eşlik ettiği bildirilse de; en sık komplike yas ve TSSB ile komorbidite gösterdiği ileri sürülmüştür (Bögels ve ark. 2013).

Alkol kullanım bozuklukları, yeme bozuklukları ve sağlıklı kişilerin dahil edildiği örneklemde YAAB ve bağımlı kişilik bozukluğu tanılarının değerlendirildiği diğer bir çalışmada; şimdiki YAAB yaygınlığı kontrol grubunda \%2, alkol kullanım bozukluğu grubunda \%6 ve bulimia nervoza tanılı hastalarda \%15 oranında tespit edilmiştir. Yaşam boyu YAAB yaygınlığı ise; kontrol grubunda \%5, alkol kullanım bozukluğu grubunda \%16, bulimia nevroza grubunda \%31 olarak bildirilmiştir. Çalışma sonuçlarına göre YAAB tanısının en sık bulimia nervozaya eşlik ettiği saptanmıştır (Loas ve ark. 2002). 
YAAB ile kişilik bozukluklarının ilişkisinin araştırıldığı bir çalışmada; kişilik bozukluğu tanısı olan hastaların olduğu grupta ayrılma anksiyetesi belirtilerinin erken başladığı, ayrılma anksiyetesi skorlarının daha yüksek olduğu ve daha kötü işlevsellik düzeyine sahip oldukları bulunmuştur (Osone ve Takahashi 2006).

Silove ve arkadaşları (2010), çocuklukta başlayan YAAB hastalarının yetişkin başlangıçlı olanlara göre daha fazla komorbid kişilik bozukluğu ( $B$ ve $C$ kümesi) tanısına sahip olduğunu saptamıştır. Loas ve arkadaşlarının (2002) çalışmasında kontrol grubunda bağımlı kişilik bozukluğu ile YAAB arasında güçlü bir ilişki belirlenmiştir. Ancak Manicavasaga ve arkadaşları (1997) YAAB ile bağımlı kişilik bozukluğunun birlikte görülme oranının sadece \%17 olduğunu belirlemiştir. Diğer bir çalışmada anksiyete kliniğindeki yetişkinlerde, YAAB ve diğer anksiyete bozukluklarında benzer oranlarda kişilik bozukluğu ek tanısı saptanmıştır (Manicavasagar ve ark. 2000). YAAB'de kişilik bozukluklarının komorbiditesiyle ilgili karışık sonuçlar bulunmaktadır, ancak YAAB, tanı kriterlerindeki benzerliklere rağmen, spesifik olarak bağımlı kişilik bozukluğu ile bağlantılı görünmemektedir (Bögels ve ark. 2013).

Geçmiş çalışmalardan elde edilen sonuçlarla, komorbid anksiyete bozuklukları ve duygudurum bozukluklarının ÇAAB/YAAB tanılı hastalarda sık olduğu bilinmektedir. Komorbidite açısından ÇAAB ve YAAB arasında farklılık olmadığı yönünde çalışmalar bulunmaktadır (Silove ve ark. 2010). Ancak çocukluk başlangıcı olan ve olmayan YAAB tanılı hastalarda komorbidite açısından farklılıklar olabileceği düşünülmektedir. Bu alanda yapılacak gelecek çalışmalar konuyu aydınlatmaya yardımcı olacaktır.

\section{Ayıricı Tanı}

Ayrılma anksiyetesi, yaygın gelişimsel bozukluklar, şizofreni ya da diğer psikotik bozuklukların kliniklerinin bir parçası olabilmektedir. Bu bozuklukların varlığında ayrılma anksiyetesi belirtileri olursa, AAB tanısı konulmamaktadır (Mancini ve ark. 2009, American Psychiatric Association 2013). Psikotik bozukluklardaki varsanılardan farklı olarak, AAB'de olağan olmayan algısal yaşantılar gerçek bir uyaranın yanlış algılanmasına dayanmaktadır ve sadece belli durumlarda ortaya çıkmaktadır ve bağlanma figürünün yanında bu algılama kaybolmaktadır (İlhan 2018).

Bazı araştırmacılar, ayrılma anksiyetesinin diğer anksiyete bozukluklarından önce geliştiğini ve panik atakların AAB'ye ikincil olabileceğini belirtmektedir (Mercer 2006). AAB olan hastalar aşırı stres veya sıkıntı olarak ortaya çıkan "panik" yaşayabilirler, ancak birincil korku panik atak geçirme korkusundan çok ayrılma korkusudur (Baldwin ve ark. 2016). AAB'de endişe bağlanma figüründen ayrılmaya odaklıken, panik bozukluktaki endişenin odak noktası kişinin kendi sağlığı ve güvenliğidir (Bögels ve ark. 2013). Agorafobik durumlar ise; kaçmanın zor olabileceği veya kişiye yardımın sağlanamayacağı yerler, durumlar olarak tanımlanmaktadır. Bunun tersine, AAB'de birincil korku, sevdiklerine ya da bağlanma figürlerine istenmeyen bir şeyin olmasıdır (Baldwin ve ark. 2016).
Yaygın anksiyete bozukluğu olan çocuk ve ergenlerde, ebeveynlerinin başına kötü bir şey geleceği endişesi sıklıkla gözlenen bulgulardandır. Bu belirti AAB ile kesişmektedir. Fakat yaygın anksiyete bozukluğunda endişe sadece ebevynlere duyulan endişe ile sınırlı değildir ve sağlık, finansal sorunlar gibi hayatın her alanı ile ilgili kişinin işlevselliğini düşüren yoğun endişeler yer almaktadır (Bögels ve ark. 2013).

YAAB tanısının bazı kişilik bozukluklarıyla ayrımının yapılması gerekmektedir. YAAB ile bağımlı kişilik bozukluğunun ayrımı önemlidir. Bağımlı kişilik bozukluğunda temel endişe, kişinin kendi fiziksel ya da duygusal durumu ile başa çıkamayacağı ile ilişkilidir. YAAB'de ise; temel endişe kaybetme odaklıdır. Bağımlı kişilik bozukluğu olanlar diğerlerine güven duyma ihtiyacı hissederler ve bu kişiler rastgele ve yaygındır, belirli figürlere odaklanmamıştır (Bögels ve ark. 2013). YAAB tanılı hastalar ayrılma anksiyetesini görece daha tutarlı ilişkilerde yaşamaktadırlar. Borderline kişilik bozukluğunda görülen 'terk edilme korkuları veya terk edilmemeye yönelik çabalar' YAAB ile karışabilmektedir. Borderline kişilik bozukluğunda genellikle bu korkular, emosyonel açıdan yoğun ve dengesiz ilişkilerden kaynaklanmaktadır. Ancak YAAB'de sürekliliği olan, dengeli ilişkilerde yaşanan ve terk edilmekten daha çok 'kaza, yaralanma, ölüm veya öngörülemeyen başka bir olay' kaynaklı ayrılıklardan korku duyulmaktadır (Cyranowski ve ark. 2002, Manicavasagar ve ark. 2010).

\section{Prognoz}

Geçmiş araştırmalarda YAAB genellikle diğer ruhsal hastalıklarda incelenmiş ve hastalığın gidişatı üzerine olumsuz etkileri olduğu belirtilmiştir. Anksiyete bozukluklarına eşlik eden YAAB tanısı varlığında, relapsların arttığı, tedaviye rağmen kalıcı semptomların devam ettiği, anksiyete bozukluklarına yönelik farmakoterapi ve psikoterapi uygulamalarına daha fazla direnç geliştiği vurgulanmıştır (Cartwright ve ark. 2006, Shear ve ark. 2006). Panik bozukluk ve YAAB birlikte bulunduğunda işlevsellikte bozulmanın daha çok olduğu ve medikal tedaviye daha dirençli olduğu bulunmuştur (Shear ve ark. 2006, Pini ve ark. 2014). Bilişsel davranışçı terapi (BDT) etkinliğini değerlendiren çalışmalarda ise; panik bozukluğa YAAB eşlik ettiğinde BDT'ye olan yanıtın medikal tedavide olduğu gibi azaldığı gösterilmiştir (Aaronson ve ark. 2008, Pini ve ark. 2012). Panik bozukluğa YAAB eşlik ettiğinde medikal tedavi ve BDT'ye yanıtın 3,7 kat oranda azaldığını gösteren Silove ve ark.nın (2010) yapmış oldukları çalışma bu verileri desteklemektedir. Ülkemizde bipolar bozukluk tanılı hastalarda AAB'nin değerlendirildiği çalışmada; çocukluk ya da yetişkin $A A B$ belirtilerinin işlevsellik alanlarını olumsuz yönde etkilediği belirlenmiştir (Sahin ve ark. 2019). Bipolar bozukluk tanılı hastaların incelendiği diğer bir çalışmada; YAAB eşlik eden hastalarda daha fazla intihar girişimi öyküsü olduğu ve işlevsellik düzeylerinin daha düşük seyrettiği gösterilmiştir (Tasdemir ve ark. 2016). Major depresif bozukluk tanılı hastalara YAAB tanısı eşlik ettiğinde, daha fazla anksiyete semptomu sergiledikleri ve antidepresan tedaviye suboptimal yanıt verdikleri belirlenmiştir (Elbay ve ark. 2021). 
AAB'nin prognozu üzerine, ÇAAB öyküsü olan kişilerin erişkin dönem bulguları ile ilgili çalışmalar bulunmaktadır. Çalışmalarda YAAB olan olguların bir kısmında ÇAAB öyküsü olduğu gösterilmiştir ya da ÇAAB tanısı olan kişilerde erişkinlikte YAAB saptanmıştır (Shear ve ark. 2006). Fakat ÇAAB'nin sadece YAAB ile ilişkili olmadığı, tüm anksiyete bozuklukları ile ilişkisi olabileceği öne sürülmektedir. ÇAAB geçmiş çalșmalarda panik bozukluğun özgül bir öncülü olarak gösterilse de sonraki bazı çalışmalarda bu durum desteklenmemiştir (Silove ve ark. 2002). Kossowsky ve arkadaşlarının (2013) yapmış olduğu metaanalizde; ÇAAB varlığının, erişkin dönemde panik bozukluk ve herhangi bir anksiyete bozukluğunun gelişimi için riski arttırdığı ancak depresyon ve madde kulanım bozuklukları için risk artışı bulunmadığı sonucuna varılmıştır. 14-22 yaş aralığında olgularla yapılan yıllık izlem çalışmasında, ayrılma anksiyetesi olan hastalarda 4 yıllık izlem süresinde gelişen panik bozukluk ve agorafobi ile ayrılma anksiyetesinin ilişkisi olduğu, benzer ilişkinin diğer anksiyete bozuklukları, alkol kullanım bozuklukları ve bipolar bozuklukta olmadığı gösterilmiştir (Brückl ve ark. 2007).

Erken çocukluk başlangıçlı AAB'nin erişkin dönemde daha yüksek oranda YAAB gelişimine neden olması beklenirken, orta-geç çocukluk dönemi başlangıcı olanların YAAB geliştirme oranının daha yüksek olduğu görülmüştür. Aynı grupta yetişkinlikte daha sık duygudurum dönemi, diğer anksiyete bozuklukları ve kişilik bozuklukları ek tanı oranlarının daha fazla olduğu görülmektedir. Bu nedenle, orta-geç çocukluk ve erken ergenlik dönemlerini kapsayan ciddi ayrilma anksiyetesi olan bireylerin genel olarak daha kötü prognoz gösterme olasılı̆̆ı bulunmaktadır (Manicavasagar ve ark. 2010). Boşanma, ölüm gibi travmatik durumlara ikincil gelişen YAAB'da epizodik seyir daha fazla olmaktadır (Manicavasaga ve ark. 1997).

\section{Tedavi}

$\mathrm{AAB}$ için standart bir tedavi yöntemi bulunmamaktadır. Diğer anksiyete bozuklukları gibi farmakoterapi ve psikoterapi ile tedavi edilmektedir. ÇAAB'de hem genel BDT, hem de bozukluğa özgü BDT etkili bulunmuştur. Ancak diğer anksiyete bozukluklarına odaklanan geleneksel BDT'nin ayrılma anksiyetesi semptomlarını azaltmadığı gözlemlenmiştir (Manicavasaga ve ark. 1997). ÇAAB'ye yönelik BDT uygulamalarında; ebeveyn eğitimi, davranış yönetimi becerileri, bozukluğa özgü psikoeğitim, işlevsiz bilişlerin düzeltilmesi, maruziyet ve yanıt önleme gibi yöntemler etkili bulunmuştur (Schneider ve ark. 2011). Çocuk-ebeveyn etkileşimini değiştirerek çocukların davranışlarını iyileştirmeye yarayan Ebeveyn-Çocuk Etkileşimi Terapisinin (Parent-Child Interaction Therapy) ÇAAB'de yararlı olacağı düşünülmektedir (Choate ve ark. 2005).

YAAB tedavisi ile ilgili veriler oldukça sınırlıdır. Panik bozukluğa yönelik BDT uygulanan hastalarda, YAAB komorbiditesi olanların olmayanlara göre tedaviden olumsuz sonuç elde etme olasillğının yaklaşık dört kat fazla olduğu bildirilmiştir. Bu sonuçların AAB'nin psikopatolojisinin BDT ile ele alınıp bilişsel yeniden yapılandırmanın yapılmamasından ileri geldiği düşünülmüştür
(Aaronson ve ark. 2008). Özellikle YAAB'ye odaklanan BDT ayrılma anksiyetesini azaltarak daha iyi sonuçlar elde edilmesini sağlayabilir (Bögels ve ark. 2013). Aileyi ele alan, destekleyici, kişinin bağlanma paternlerini ve emosyonlarını anlayabilen duygu odaklı terapilerin etkili olabileceği düşünülmektedir (Milrod ve ark. 2014).

$\mathrm{AAB}$ tanılı çocukların da bulunduğu anksiyete bozukluğu tanılı hasta gruplarında fluoksetin tedavisi etkili bulunmuştur (Bögels ve ark. 2013). Seçici serotonin geri alım inhibitörü ve 5HT1a reseptör parsiyel agonisti vilazodon ile takip edilen YAAB tanılı hastaların değerlendirildiği pilot çalışmada; ayrılma anksiyetesi belirtilerinde plaseboya göre daha anlamlı düzelme belirlenmiştir ve vilazodonun YAAB tedavisinde etkili olabileceği sonucuna varılmıştır (Schneier ve ark. 2017). Altmış yaşın üstünde ayrılma anksiyetesi nadir görülmektedir. $\mathrm{Bu}$ kişilerin dikkatli takibi başka duygudurum bozukluklarının ortaya çıkmasının önlenmesi için önem taşımaktadır (Wijeratne ve Manicavasagar 2003).

\section{Sonuç}

AAB; DSM-5'te yaş kriterinin ortadan kaldırılmasıyla, herhangi bir yaşta tanı alınabilen bir hastalık haline gelmiştir. Günümüzde YAAB'nin her iki cinsiyette yaygın görülen bir ruhsal hastalık olduğu bilinmektedir ve etiyolojisi bağlanma kuramı, genetik, nörobiyoloji gibi faktörlerle açıklanmaya çalışılmaktadır. Literatürde YAAB sıklıkla diğer ruhsal hastalıklarda incelenmiş ve hastalığın gidişatını, tedavi yanıtını olumsuz etkilediği, işlevsellikte azalmaya yol açabildiği gösterilmiştir. Ancak YAAB'ye yönelik bilgiler halen tam anlamılla yeterli değildir. Gidişata etkisinin ve yordayıcı olabileceği klinik durumların belirlenmesi amacıyla yapılacak takip çalışmalarına ve etkili tedavi yaklaşımlarının araştırılmasına ihtiyaç bulunmaktadır. Birincil olarak YAAB tanısına odaklanan, çocukluk başlangıcı olan ve olmayan hastaların karş̧laş̧ııııldığı çalışmalar hastalık hakkında daha fazla bilgi sağlayacaktır.

Yazarların Katkıları: Yazarlar çalışmaya önemli bir bilimsel katkı sağladıklarını ve makalenin hazırlanmasında veya gözden geçirilmesinde yardımcı olduğunu kabul etmiştir.

Danışman Değerlendirmesi: Dış bağımsız.

Çıkar Çatışması: Yazarlar çıkar çatışması bildirmemiştir.

Finansal Destek: Yazarlar bu çalışma için finansal destek almadığını beyan etmiştir.

Authors Contributions: The authors attest that she has made an important scientific contribution to the study and has assisted with the drafting or revising of the manuscript.

Peer-review: Externally peer-reviewed.

Conflict of Interest: No conflict of interest was declared by the authors. Financial Disclosure: The authors declared that this study has received no financial support.

\section{Kaynaklar}

Aaronson CJ, Shear K, Goetz RR, Allen LB, Barlow DH, White KS et al. (2008) Predictors and time course of response among panic disorder patients treated with cognitive-behavioral therapy. J Clin Psychiatry, 69:418-424. 
Abelli M, Chelli B, Costa B, Lari L, Cardini A, Gesi C et al. (2010) Reductions in platelet $18-\mathrm{kDa}$ translocator protein density are associated with adult separation anxiety in patients with bipolar disorder. Neuropsychobiology, 62:98-103.

Ainsworth MDS (1982) The place of attachment theory in human behavior. New York, Basic Books.

Alfano CA, Beidel DC, Turner SM (2002) Cognition in childhood anxiety: Conceptual, methodological, and developmental issues. Clin Psychol Rev, 22:1209-1238

Alkın T (2010) Yetişkin ayrılma anksiyetesi bozukluğu. Türkiye Klinikleri J Psychiatry- Special Topics, 3:53-63.

APA (1987) DSM-III-R: Diagnostic and Statistical Manual of Mental Disorders. 3rd edition revised. Washington, DC, American Psychiatric Association.

APA (1994) Diagnostic and Statistical Manual of Mental Disorders, 4th ed., text revision (DSM-IV-TR). Washington, DC, American Psychiatric Association.

APA (2013) Diagnostic and Statistical Manual of Mental Disorders, 5th ed., (DSM-5). Washington, DC, American Psychiatric Association.

Atlı Ö (2011) Panik bozukluğu ve yetişkin ayrılma anksiyetesi bozukluğu hastalarında CO2 duyarlılığı (Uzmanlık tezi). İzmir, Dokuz Eylül Üniversitesi.

Baldwin DS, Gordon R, Abelli M, Pini S (2016) The separation of adult separation anxiety disorder. CNS Spectr, 21:289-294.

Başbuğ S, Cesur G, Durak-Batıgün A (2016) Algılanan ebeveynlik biçimi ve yetişkin ayrılma anksiyetesi: kişilerarası bilişsel çarpıtmaların aracı rolü. Türk Psikiyatri Derg, 27:1-13.

Bögels SM, van Dongen L, Muris P (2003) Family influences on dysfunctional thinking in anxious children. Inf Child Dev, 12:243-252.

Bögels SM, Knappe S, Clark LA (2013) Adult separation anxiety disorder in DSM-5. Clin Psychol Rev, 33:663-674.

Bolton D, Eley TC, O'Connor T, Perrin S, Rabe-Hesketh S, Rijsdijk F et al. (2006) Prevalence and genetic and environmental influences on anxiety disorders in 6-year-old twins. Psychol Med, 36:335-344

Bowlby J (1973) Attachment and Loss: Volume II: Separation, Anxiety and Anger. New York, Basic Books.

Bowlby J (1980) Loss, Sadness and Depression. London, Penguin.

Brückl TM, Wittchen HU, Höfler M, Pfister H, Schneider S, Lieb R (2007) Childhood separation anxiety and the risk of subsequent psychopathology: Results from a community study. Psychother Psychosom, 76:47-56.

Cartwright-Hatton S, McNicol K, Doubleday E (2006) Anxiety in a neglected population: Prevalence of anxiety disorders in pre-adolescent children. Clin Psychol Rev, 26:817-833.

Chelli B, Pini S, Abelli M, Cardini A, Lari L, Muti M et al. (2008) Platelet 18 $\mathrm{kDa}$ translocator protein density is reduced in depressed patients with adult separation anxiety. Eur Neuropsychopharmacol, 18:249-254.

Choate ML, Pincus DB, Eyberg SM, Barlow DH (2005) Parent-child interaction therapy for treatment of separation anxiety disorder in young children: A pilot study. Cogn Behav Pract, 12:126-135.

Coldur EO, Cokmus FP, Suculluoglu Dikici D, Aydemir O (2020) The validity and reliability of DSM-5 separation anxiety disorder severity scale-adult form. Dusunen Adam, 33:237-243.

Costa B, Pini S, Martini C, Abelli M, Gabelloni P, Landi S et al. (2009a) Ala147 Thr substitution in translocator protein is associated with adult separation anxiety in patients with depression. Psychiatr Genet, 19:110-111.

Costa B, Pini S, Martini C, Abelli M, Gabelloni P, Ciampi O et al. (2009b) Mutation analysis of oxytocin gene in individuals with adult separation anxiety. Psychiatry Res, 168:87-93.
Costello EJ, Mustillo S, Erkanli A (2003) Prevalence and development of psychiatric disorders in childhood and adolescence. Arch Gen Psychiatry, 60:837-844.

Cyranowski JM, Shear MK, Rucci P, Fagiolini A, Frank E, Grochocinski VJ et al. (2002) Adult separation anxiety: Psychometric properties of a new structured clinical interview. J Psychiatr Res, 36:77-86.

Da Pozzo E, Costa B, Martini C (2012) Translocator protein (TSPO) and neurosteroids: implications in psychiatric disorders. Curr Mol Med, 12:426-442.

Dashiff CJ, Weaver M (2008) Development and testing of a scale to measure separation anxiety of parents of adolescents. J Nurs Meas, 16:61-80.

Demir NÖ, Görgülü Y (2020) Bir üniversite hastanesi psikiyatri polikliniğine başvuran yaygın anksiyete bozukluğu tanılı hastalarda ayrılma anksiyetesi bozukluğu görülme sıklı̆̆. Klinik Psikiyatr Dergisi, 23:188-195.

Diriöz M, Alkin T, Yemez B, Onur E, Eminağaoğlu N (2012a) Ayrılma anksiyetesi belirti envanteri ile yetişkin ayrılma anksiyetesi anketinin Türkçe versiyonunun geçerlik ve güvenirliği. Turk Psikiyatri Derg, 23:108-116.

Diriöz M, Alkin T, Yemez B, Eminagaoglu N, Onur E (2012b) Ayrilma anksiyetesi belirtileri için yapilandirilmis klinik görüsmesi Türkçe versiyonunun psikometrik özellikleri/Psychometric properties of the Turkish version of the structural clinical interview for separation anxiety symptoms. Noro Psikyatr Ars, 49:6-13.

Ditommaso E, Brannen-McNulty C, Ross L, Burgess M (2003) Attachment styles, social skills and loneliness in young adults. Pers Individ Diff, 35:303312

Eapen V, Silove DM, Johnston D, Apler A, Rees S (2012) Adult separation anxiety in pregnancy: how common is it? Int J Women's Health, 4:251-256.

Eaves L, Silberg JL, Meyer JM, Maes HH, Simonoff E, Pickles A e al. (1997) Genetics and developmental psychopatology: 2. the main effects of genes and environment on behavioral problems in the Virginia twin study of adolescent behavioral development. J Child Psychol Psychiat, 38:965-980.

Ehringer MA, Rhee SH, Young S, Corley R, Hewitt JK (2006) Genetic and environmental contributions to common psychopathologies of childhood and adolescence: A study of twins and their Siblings. J Abnorm Child Psychol, 34:1-17.

Elbay RY, Görmez A, Kılıç A, Avcı SH (2021) Separation anxiety disorder among outpatients with major depressive disorder: Prevalence and clinical correlates. Compr Psychiatry, 105:152219.

Eley TC, Rijsdijk FV, Perrin S, O'Connor TG, Bolton D (2008) A multivariate genetic analysis of specific phobia, separation anxiety and social phobia in early childhood. J Abnorm Child Psychol, 36:839-848.

Foley DL, Pickles A, Maes HM, Silberg JL, Eaves LJ (2004) Course and shortterm outcomes of separation anxiety disorder in a community sample of twins. J Am Acad Child Adolesc Psychiatry, 43:1107-1114.

Franz AP, Rateke L, Hartmann T, McLaughlin N, Torres AR, do Rosario MC et al. (2015) Separation anxiety disorder in adult patients with obsessivecompulsive disorder: Prevalence and clinical correlates. Eur Psychiatry, 30:145-151.

Gadow KD, DeVincent CJ, Olvet DM, Pisarevskaya V, Hatchwell E (2010) Association of DRD4 polymorphism with severity of oppositional defiant disorder, separation anxiety disorder and repetitive behaviors in children with autism spectrum disorder. Eur J Neurosci, 32:1058-1165.

Gillath O, Shaver PR, Baek JM, Chun DS (2008) Genetic correlates of adult attachment style. Pers Soc Psychol Bull, 34:1396-1405.

Gregory AM, Eley TC (2007) Genetic influences on anxiety in children: What we've learned and where we're heading. Clin Child Fam Psychol Rev, 10:199-212.

Heinrichs N, Rapee RM, Alden LA, Bögels S, Hoffman SG, Oh KJ et al. (2006) Cultural differences in perceived social norms and social anxiety. Behav Res Ther, 44:1187-1197. 
Hock E, McBride SL, Gnezda T (1989) Maternal separation: Mother-infant separation from the maternal perspective. Child Dev, 60:793-802.

İlhan E (2018) Yetişkin ayrılma anksiyetesi ve bağlanma arasındaki ilişki (Yüksek lisans tezi). İstanbul, İstanbul Gelişim Üniversitesi.

Karamustafalığlu O, Yumrukçal H (2011) Depresyon ve anksiyete bozuklukları. Şişli Etfal Hastanesi Tıp Bülteni, 45:65-74.

Kessler RC, Wang PS (2008) The descriptive epidemiology of commonly occurring mental disorders in the United States. Annu Rev Public Health, 29:115-129.

Kirsch P, Esslinger C, Chen Q, Mier D, Lis S, Siddhanti S et al. (2005) Oxytocin modulates neural circuitry for social cognition and fear in humans. J Neurosci, 25:11489-11493.

Kossowsky J, Pfaltz MC, Schneider S, Taeymans J, Locher C, Gaab C (2013) The separation anxiety hypothesis of panic disorder revisited: A metaanalysis. Am J Psychiatry, 170:768-781.

Lahey BB (2009) Public health significance of neuroticism. Am Psychol, 64:241-256.

Leyfer O, Janet WB, Carolyn BM (2009) Anxiety disorders in children with williams syndrome, their mothers, and their siblings: Implications for the etiology of anxiety disorders. J Neurodev Disord, 1:4-14.

Loas G, Atger F, Perdereau F, Verrier A, Guelfi JD, Halfon O et al. (2002) Comorbidity of dependent personality disorder and separation anxiety disorder in addictive disorders and in healthy subjects. Psychopathology, 35:249-253.

Mancini AD, Robinaugh D, Shear K, Bonanno GA (2009) Does attachment avoidance help people cope with loss? The moderating effects of relationship quality. J Clin Psychol, 65:1127-1136.

Manicavasagar V, Marnane C, Pini S, Abelli M, Rees S, Eapen V et al. (2010) Adult separation anxiety disorder: A disorder comes of age. Curr Psychiatry Rep, 12:290-297.

Manicavasaga V, Silove D, Curtis J (1997) Separation anxiety in adulthood: A phenomenological investigation. Compr Psychiatry, 38:274-282.

Manicavasagar V, Silove D, Curtis J, Wagner R (2000) Continuities of separation anxiety from early life into adulthood. J Anxiety Disord, 14:1-18.

Manicavasagar V, Silove D, Marnane C, Wagner R (2009) Adult attachment styles in panic disorder with and without comorbid adult separation anxiety disorder. Aust N Z J Psychiatry, 43:167-172.

Manicavasagar V, Silove D, Rapee R, Waters F, Momartin S (2001) Parentchild concordance for separation anxiety: A clinical study. J Affect Disord, 65:81-84.

Manicavasagar V, Silove D, Wagner R, Drobny J (2003) A self-report questionnaire for measuring separation anxiety in adulthood. Compr Psychiatry, 44:146-153.

Manicavasagar V, Silove D, Wagner R, Hadzi-Pavlovic D (1999) Parental representations associated with adult separation anxiety and panic disorderagoraphobia. Aust N Z J Psychiatry, 33:422-428.

Mayseless O, Scher A (2000) Mother's attachment concerns regarding spouse and infant's temperament as modulators of maternal separation anxiety. J Child Psychol Psychiat, 41:917-925.

Meinlschmidt G, Heim C (2007) Sensitivity to intranasal oxytocin in adult men with early parental separation. Biol Psychiatry, 61:1109-1111.

Mercer Jean (2006) Understanding Attachment: Parenting, Child Care, and Emotional Development. Portsmouth, Greenwood Publishing Group.

Milrod B, Markowitz JC, Gerber AJ, Cyranowski J, Altemus M, Shapiro T et al. (2014) Childhood separation anxiety and the pathogenesis and treatment of adult anxiety. Am J Psychiatry, 171:34-43.

Nestadt G, Samuels J, Riddle MA, Liang KY, Bienvenu OJ, Hoehn-Saric R et al. (2001) The relationship between obsessive-compulsive disorder and anxiety and affective disorders: Results from the Johns Hopkins OCD family study. Psychol Med, 31:481-487.
Ogliari A, Spatola CA, Pesenti-Gritti P, Medda E, Penna L, Stazi MA et al. (2010) The role of genes and environment in shaping co-occurrence of DSMIV defined anxiety dimensions among Italian twins aged 8-17. J Anxiety Disord, 24:433-439.

Osone A, Takahashi S (2006) Possible link between childhood separation anxiety and adulthood personality disorder in patients with anxiety disorders in Japan. J Clin Psychiatry, 67:1451-1457.

Peleg O, Halaby E, Whaby EN (2006) The relationship of maternal separation anxiety and differentiation of self to children's separation anxiety and adjustment to kindergarten: A study in Druze families. J Anxiety Disord, 20:973-995.

Pine DS, Klein RG, Roberson R (2005) Response to 5\% carbon dioxide in children and adolescents: Relationship to panic disorder in parents and anxiety disorders in subjects. Arch Gen Psychiatry, 62:73-80.

Pine DS, Wasserman GA, Workman SB (1999) Memory and anxiety in prepubertal boys at risk for delinquency. J Am Acad Child Adolesc Psychiatry, 38:1024-1131.

Pini S, Abelli M, Shear KM, Cardini A, Lari L, Gesi C et al. (2010) Frequency and clinical correlates of adult separation anxiety in a sample of 508 outpatients with mood and anxiety disorders. Acta Psychiatr Scand, 122:4046

Pini S, Abelli M, Troisi A, Siracusano A, Cassano GB, Shear KM et al. (2014) The relationships among separation anxiety disorder, adult attachment style and agoraphobia in patients with panic disorder. J Anxiety Disord, 28:741-746.

Pini S, Gesi C, Abelli M, Muti M, Lari L, Cardini A et al. (2012) The relationship between adult separation anxiety disorder and complicated grief in a cohort of 454 outpatients with mood and anxiety disorders. J Affect Disord, 143:64-68.

Pini S, Martini C, Abelli M, Muti M, Gesi C, Montali M et al. (2005) Peripheral-type benzodiazepine receptor binding sites in platelets of patients with panic disorder associated to separation anxiety symptoms. Psychopharmacology, 181:407-411.

Quirin M, Gillath O, Pruessner JC, Eggert LD (2010) Adult attachment insecurity and hippocampal cell density. Soc Cogn Affect Neurosci, 5:39-47.

Quirin M, Pruessner JC, Kuhl J (2008) HPA system regulation and adult attachment anxiety: Individual differences in reactive and awakening cortisol. Psychoneuroendocrinology, 33:581-590.

Roberson囚Nay R, Eaves LJ, Hettema JM, Kendler KS, Silberg JL (2012) Childhood separation anxiety disorder and adult onset panic attacks share a common genetic diathesis. Depress Anxiety, 29:320-327.

Sahin G, Durat G, Sahin S (2019) Bipolar bozukluk hastalarında ayrilma anksiyetesi ve işlevselliğin değerlendirilmesi. Anadolu Psikiyatri Derg, 20:60-68

Schneier FR, Moskow DM, Choo TH, Galfalvy H, Campeas R, SanchezLacay A (2017) A randomized controlled pilot trial of vilazodone for adult separation anxiety disorder. Depress Anxiety, 34:1085-1095.

Schneider S, Blatter-Meuiner J, Herren C, Adornetto C, In-Albon T, Lavallee K (2011) Disorder-specific cognitive-behavioral therapy for separation anxiety disorder in young children: a randomized waiting-list-controlled trial. Psychother Psychoom, 80:206-215.

Seligman LD, Wuyek LA (2007) Correlates of separation anxiety symptoms among first-semester college students: An exploratory study. J Psychol, 141:135-145

Shear K, Jin R, Ruscio AM, Walters EE, Kessler RC (2006) Prevalence and correlates of estimated DSM-IV child and adult separation anxiety disorder in the national comorbidity survey replication. Am J Psychiatry, 163:10741083.

Silove D, Alonso J, Bromet E, Gruber M, Sampson N, Scott K, et al. (2015) Pediatric-onset and adult -onset separation anxiety disorder across countries in the world mental health survey. Am J Psychiatry, 172:647-656. 
Silove D, Manicavasagar V, Drobny J (2002) Associations between juvenile and adult forms of separation anxiety disorder: A study of adult volunteers with histories of school refusal. J Nerv Ment Dis, 190:413-415.

Silove D, Manicavasagar V, O'connell D, Blaszcynski A, Wagner R, Henry J (1993) The development of the Separation Anxiety Symptom Inventory (SASI). Aust N Z J Psychiatry, 27:477-488.

Silove D, Manicavasagar V, O'connell D, Yates M (1995) Genetic factors in early separation anxiety: Implications for the genesis of adult anxiety disorders. Acta Psychiatr Scand, 92:17-24.

Silove DM, Marnane CL, Wagner R, Manicavasagar VL, Rees S (2010) The prevalence and correlates of adult separation anxiety disorder in an anxiety clinic. BMC Psychiatry, 10:21.

Silove D, Slade T, Marnane C, Wagner R, Brooks R, Manicavasagar V (2007) Separation anxiety in adulthood: Dimensional or categorical? Compr Psychiatry, 48:546-553.

Strober M, Freeman R, Lampert C, Diamond J (2007) The association of anxiety disorders and obsessive compulsive personality disorder with anorexia nervosa: Evidence from a family study with discussion of nosological and neurodevelopmental implications. Int J Eat Disord, 40:4651.

Tasdemir A, Tamam L, Keskin N, Evlice YE. (2016) Assessment of comorbidity of adult separation anxiety in patients with bipolar disorder. Nord J Psychiatry, 70:93-102.
Tops M, Van Peer JM, Korf J, Wijers AA, Tucker DM (2007) Anxiety, cortisol, and attachment predict plasma oxytocin. Psychophysiology, 44:444-449.

Van Ijzendoorn MH, Bakermans-Kranenburg MJ (2006) DRD4 7-repeat polymorphism moderates the association between maternal unresolved loss or trauma and infant disorganization. Attach Hum Dev, 8:291-307.

Vanderwerker LC, Jacobs SC, Parkes CM, Prigerson HG (2006) An exploration of associations between separation anxiety in childhood and complicated grief in later life. J Nerv Ment Dis, 194:121-123.

Vasa RA, Nay RR, Klein RG, Mannuzza S, Moulton JL, Guardino M et al. (2007) Memory deficits in children with and at risk for anxiety disorders. Depress Anxiety, 24:85-94.

Vrtička P, Andersson F, Grandjean D, Sander D, Vuilleumier P (2008) Individual attachment style modulates human amygdala and striatum activation during social appraisal. PloS One, 3:e2868.

Weinfield NS, Ogawa JR, Sroufe LA (1997) Early attachment as a pathway to adolescent peer competence. J Res Adolesc, 7:241-265.

Wijeratne C, Manicavasagar V (2003) Separation anxiety in the elderly. J Anxiety Disord, 17:695-702.

Wilhelm K, Boyce P, Brownhill S (2004) The relationship between interpersonal sensitivity, anxiety disorders and major depression. J Affect Disord, 79:33-41.

Wood JJ (2007) Parental intrusiveness and children's separation anxiety in a clinical sample. Child Psychiatry Hum Dev, 37:73-87. 